\title{
Effective Chiral Thiophene Diamine Derivatives in Pd-Catalyzed Enantioselective Allylic Alkylation
}

\author{
Sang-Han Kím, Eun-Kyung Lee, and Geon-Joong Kim \\ Department of Chemical Engineering, Inha Liviversity; Inchon 402-751. Korea \\ Received November 18,2003
}

Key Words : Allylic alkylation. Pd-catalyzed. Thiophene diamines

Enantioselective allylic alkylations have been widely employed as efficient and convenient tools for carboncarbon bond formation in the lield of organic synthesis.' During the last decade, various chiral ligands have been developed for Pd-catalyzed enantioselective allylic alkylation.2 In particular, high levels of asymmetric induction have been achicved using the palladium complexes of phosphineoxazoline hybrid ligands, amidine. ${ }^{+}$Tetradentate bisphosphinobioxazolines ligands, ${ }^{5}$ sulfur-imine type chiral ligands. various $\mathrm{S}, \mathrm{N}$ ligands ${ }^{7}$ containing oxazoline moiety are also known to alford a high enantioselectivity. However tetradentate sulfur-nitrogen ligands such as chiral thiophene diamine derivatives, have never been examined as ligands in

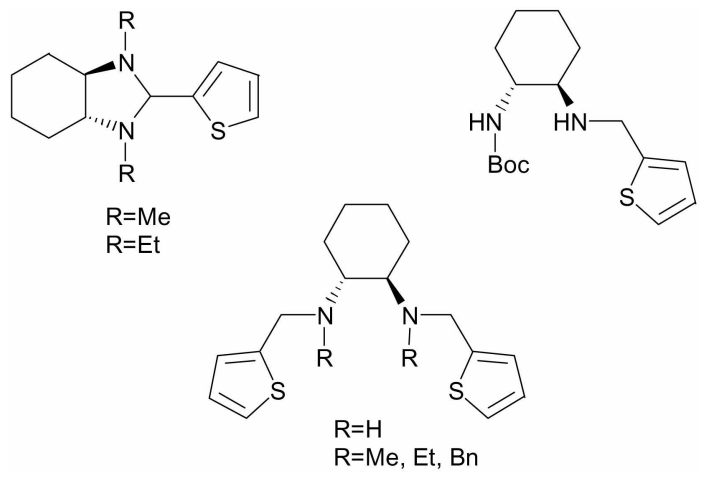

Table 1. Pd-catalyzed enantioselective allylic alkylation of 1.3-diphenyl-2-propenyl acetate using the chiral ligands 3.5. 10. 12 and 13-15

\begin{tabular}{|c|c|c|c|c|c|c|c|c|}
\hline \multirow[b]{2}{*}{ Entry } & \multirow[b]{2}{*}{ l.igand (mol \%) } & \multicolumn{4}{|c|}{$\begin{array}{c}{\left[\mathrm{Pd}\left(\eta^{3}-\mathrm{C}_{3} \mathrm{H}_{5}\right) \mathrm{Cl}\right]_{2}} \\
\text { chiral ligand } 3,5, \mathbf{1 0}, 12 \text { and 13-15 } \\
\mathrm{CH}_{2}\left(\mathrm{CO}_{2} \mathrm{Me}\right)_{2} \\
\text { BSA-additive } \\
\text { solvent }\end{array}$} & \multirow[b]{2}{*}{ lime (h) } & \multirow{2}{*}{$\overbrace{\mathrm{Ph}}^{\mathrm{CH}\left(\mathrm{CO}_{2} \mathrm{Me}\right)_{2}}$} & \multirow[b]{2}{*}{ ee $(\%)^{h}$ (Conlig.') } \\
\hline & & $\mathrm{L} * \mathrm{Pd}$ & Jemp. $\left({ }^{\circ} \mathrm{C}\right)$ & Solvent & Additive & & & \\
\hline 1 & $3(10)$ & $4 / 1$ & 20 & 'THI: & I,jOAC & 22 & 65 & oo(s) \\
\hline 2 & $5(10)$ & 41 & 20 & THF & LIOAC & 22 & 70 & $70.8(S)$ \\
\hline 3 & $5(10)$ & $4 / 1$ & 20 & THI: & $\mathrm{KO} \mathrm{Ac}$ & 22 & 80 & $61(S)$ \\
\hline 4 & $10(10)$ & 41 & 20 & ТHГ & $\mathrm{KO} \wedge \mathrm{C}$ & 22 & 70 & $80(R)$ \\
\hline 5 & $12(10)$ & $4: 1$ & 20 & THF & $\mathrm{KOAC}$ & 22 & 83 & $94.8(R)$ \\
\hline 6 & $12(10)$ & 41 & 20 & $\mathrm{CH}_{2} \mathrm{Cl}_{2}$ & $\mathrm{KO} \wedge \mathrm{c}$ & 12 & 65 & $88.0(\mathrm{R})$ \\
\hline 7 & $12(10)$ & $1: 1$ & 20 & THF & $\mathrm{KOAC}$ & 48 & 50 & $88.5(\mathrm{R})$ \\
\hline 8 & $12(10)$ & 41 & 20 & 'THII & $\mathrm{I}, \mathrm{jO} / \mathrm{Ac}$ & 12 & 74 & $88.3(\mathrm{R})$ \\
\hline 9 & $12(10)$ & 41 & 20 & $\mathrm{CH}_{2} \mathrm{Cl}_{2}$ & LIOAC & 12 & 30 & $78.6(\mathrm{R})$ \\
\hline 10 & $12(10)$ & $4 / 1$ & 0 & $\mathrm{CH}_{2} \mathrm{Cl}_{2}$ & $\mathrm{KOAC}$ & 48 & 98 & $90(\mathrm{R})$ \\
\hline 11 & $12(10)$ & $2.5 / 1$ & 20 & ТНГ & $\mathrm{KOAC}$ & 22 & 85 & $90(\mathrm{R})$ \\
\hline 12 & $13(10)$ & $4 / 1$ & 20 & $\mathrm{CH}_{2} \mathrm{Cl}_{2}$ & $\mathrm{KOAC}$ & 12 & 99 & $65(\mathrm{R})$ \\
\hline 13 & $13(10)$ & 41 & 20 & 'THI: & $\mathrm{KOAC}$ & 12 & 88 & $6(\mathrm{R})$ \\
\hline 14 & $13(10)$ & 41 & 20 & $\mathrm{CH}_{2} \mathrm{Cl}_{2}$ & LIOAC & 12 & 99 & $93.7(R)$ \\
\hline 15 & $13(10)$ & 41 & 20 & 'THE: & I.jOAC & 22 & 80 & $98(R)$ \\
\hline 16 & $13(10)$ & 41 & 0 & $\mathrm{CH}_{2} \mathrm{Cl}_{2}$ & $\mathrm{LiOAC}$ & 18 & 20 & $93.7(R)$ \\
\hline 17 & $13(10)$ & $4 / 1$ & 0 & 'THIF' & $1 . \mathrm{iOAC}$ & 18 & 30 & $94.5(\mathrm{R})$ \\
\hline 18 & $14(10)$ & 41 & 20 & ТHГ & $\mathrm{KO} / \mathrm{C}$ & 18 & 15 & $25(\mathrm{R})$ \\
\hline 19 & $14(10)$ & $4 / 1$ & 20 & $\mathrm{CH}_{2} \mathrm{Cl}_{2}$ & $\mathrm{KOAC}$ & 22 & 20 & $35(R)$ \\
\hline 20 & $15(10)$ & 41 & 20 & $\mathrm{CH}_{2} \mathrm{Cl}_{2}$ & $\mathrm{KOAC}$ & 20 & 18 & $33(\mathrm{R})$ \\
\hline 21 & $15(10)$ & 41 & 20 & $\mathrm{CH}_{2} \mathrm{Cl}_{2}$ & LIOAC & 20 & 23 & $42(R)$ \\
\hline
\end{tabular}

"The conversion was determined by GC analysis. "The enantioneric excess was determined by I IPI.C with chiralcel OD $\mathrm{column}(25 \mathrm{~cm} \times 0.46 \mathrm{~cm})$ : I\% 2-propanol in hexane, llow rate $0.5 \mathrm{~mL} / \mathrm{min}$. "Absulute conliguration wäls alssigned by the elution order lrom a Daicel chiralcel column. 
this reaction to date. Here in, we wish to report palladiumcatalyzed enantioselective allylic alkylation using chiral thiophene diamine derivatives which were prepared from enantiomerically pure $(R, R)$-1,2-diaminocyclohexane.

To examine the effectiveness of the thiophene diamine derivatives as chiral ligands in palladium-catalyzed enantioselective allylic alkylation, the reaction between rac-1,3diphenyl-2-propenyl acetate and dimethyl malonate has been investigated under standard conditions in the presence of $\mathrm{N}, \mathrm{O}$-bis(trimethylsilyl) acetamide (BSA) and KOAc or LiOAc as base. ${ }^{8}$

The results are summarized in Table 1 . As shown in Table 1 , the enantioselectivity is strongly dependant on the structure of thiophene diamine derivatives.

The tetradentate thiophene diamine derivatives 12 and 13 are proved to be very efficient in terms of enantioselectivity in the reaction. In particular. $N, N$-dimethyl derivative $\mathbf{1 3}$ affords the alkylation product with up to $98 \%$ ee. The results are comparable to those to phosphinooxazolines. ${ }^{9}$ In case of ligand 12 , use of $\mathrm{THF}$ as solvent is more desirable than $\mathrm{CH}_{2} \mathrm{Cl}_{2}$. The reduction of temperature to 0 " $\mathrm{C}$ seems to have little effect on the enantioneric excess. BSA-KOAc as additive source gave somewhat better enantioselectivity. And then, in case of ligand 13, solvent exchange and reduction of temperature didn't play a key role in the enantioselectivity. Surprisingly, however, additive sources showed great difference in the enantioselectivity. BSA-LiOAc gave much better enantioselectivity. Moreover, we investigated the influence of the ratio of ligand versus palladium on the enantiomeric excess, and observed an increase in the ee value with the amount of ligand introduced. The best result in enantioselectivity was obtained when the ratio of ligandipalladium was $4 / 1$. It has been found that poor results were obtained in terms of enantioselective and reactivity in case of ligand $\mathbf{1 4}$ and $\mathbf{1 5}$. In contrast, bidentate thiophene diamine derivatives $\mathbf{3}$ and $\mathbf{5}$ gave moderate asymmetric induction and modest reactivity.

Although the chelation mode of ligand with Pd metal is not clear, asymmetric induction by ligand $\mathbf{1 3}$ can be explain-

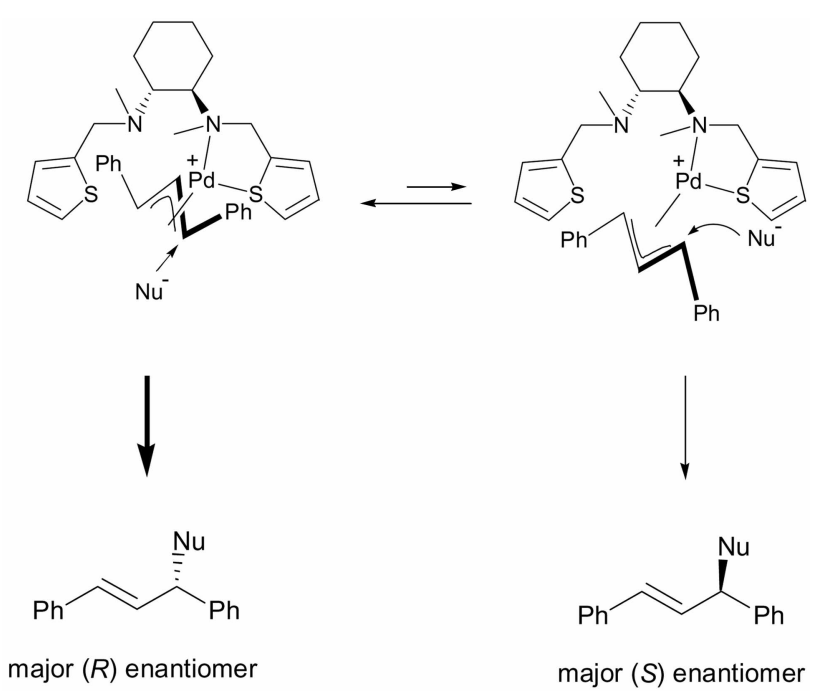

ed as follows. P'robably, a nucleophilic attack to $\pi$-allylpalladium complex proceeds predominantly at the allyl terminus trans to the better-acceptor. Thus, the nucleophile addition could proceed through the complex having a $W$ shaped allyl part as a major path that which led to $(R)$ configuration as illustrated in Scheme 1.

In conclusion, we have developed the effective of chiral ligands, bi-, tri- and tetradentate thiophene diamine derivatives, for the Pd-catalyzed enantioselective allylic alkylation. These chiral ligands could be applied successfully and the high enantioselectivities were attainable in this enantioselective allylic alkylation.
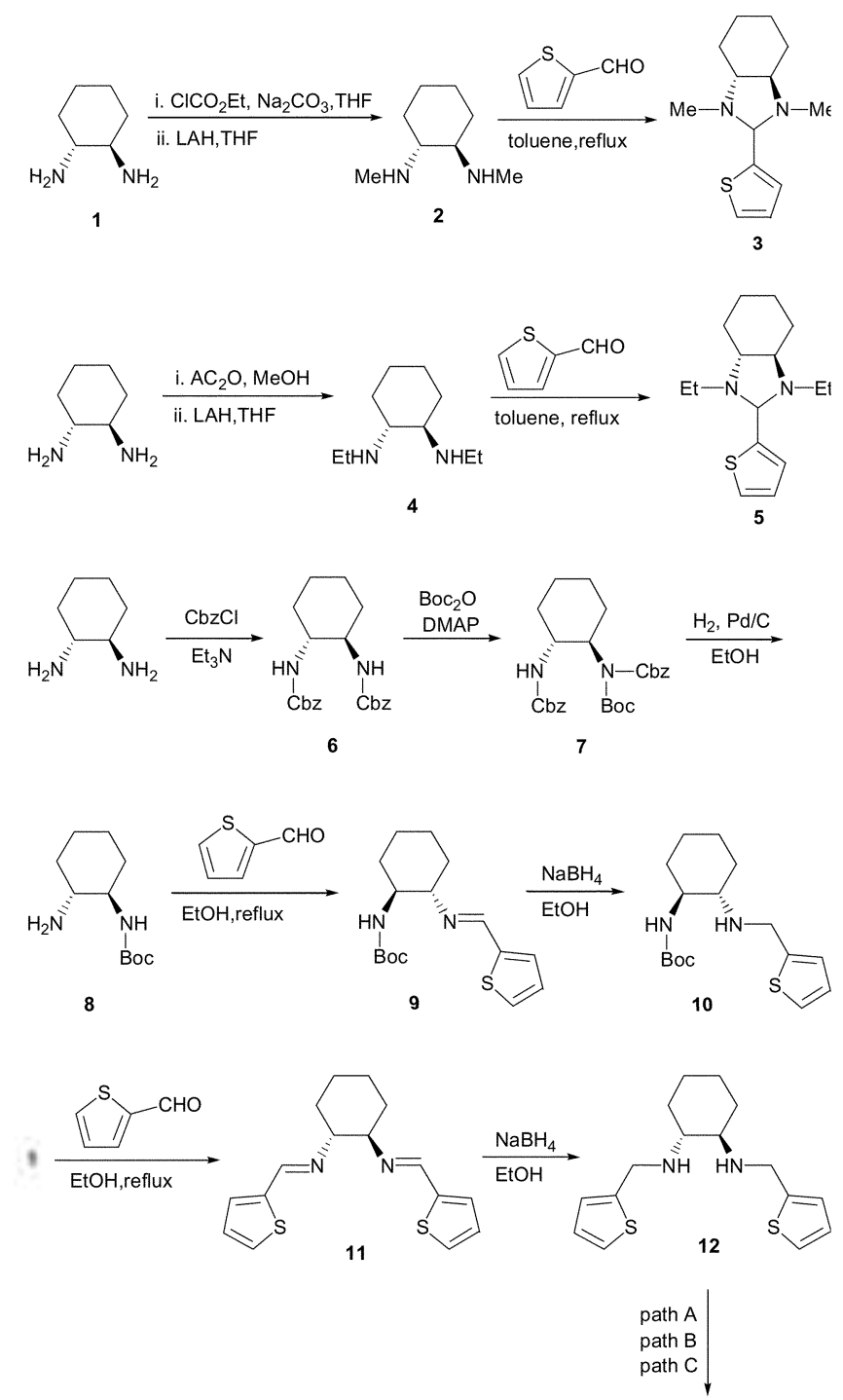

parh A : i. CICO, Et, $\mathrm{Na}_{2} \mathrm{CO}_{3,}$ THF; ii. LAH, FHF for 13 parh $B$ : i. ACOH, MeOH : it. LAH. THF for 14 parh C: i. BnCl. Ela $\mathrm{N}$ THF for 15

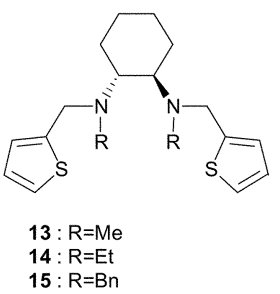

Scheme 1

Scheme 2 


\section{Experimental Section}

Generals: NMR spectra were recorded at $400 \mathrm{MHz}\left({ }^{\mathrm{l}} \mathrm{H}\right.$ and ${ }^{13} \mathrm{C}$ ) using a Varian Unity INOVA400 Spectrometer. FTIR spectra were obtained on BRUKER IFS 48 spectrometer. $\mathrm{CH}_{2} \mathrm{Cl}_{2}$ was distilled from $\mathrm{CaH}_{2}$. Tetrahydrofuran was refluxed over sodium at least for $5 \mathrm{~h}$ under nitrogen atmosphere. $(R R)$-1.2-dianinocyclohexane was purchased from Aldrich. All experiments were conducted under an atmosphere of nitrogen. Optical rotations were measured on a Perkin Elmer 241 polarimeter and were reported using l-dn cell along with the solvent and concentration in $\mathrm{g} / 100 \mathrm{~mL}$. Flash chromatography was carried out using Merck silica gel 60 ( 230 to 400 mesh). The enantiomeric excesses of the product were deternined by HPLC (Daicel chiralcel OD-H colunin, $25 \mathrm{~cm} \times 0.46 \mathrm{cml} . \lambda 25+\mathrm{nm} .1 \% 2$-propanol in hexane, $0.5 \mathrm{~mL} / \mathrm{min}$.)

Schene 2 shows the method to synthesize the bidentate chiral thiophene diamine derivatives ( 3 and 5 ), tri- and tetradentate thiophene diamine derivatives $(10,12$ and 1315). These chiral ligands can be readily derived from enantiomerically pure $(R R)$-1.2-dianinocyclohexane 1 and 2-thiophenecarboxaldehyde. The chiral ligand 12 can be readily synthesized by condensation of enantionerically pure $(R, R)$-1,2-diaminocyclohexane 1 and 2-thiophenecarboxadehyde in the refluxing ethanol. followed by reduction with $\mathrm{NaBH}_{4}$ at room temperature for $6 \mathrm{~h}$. The chiral ligand $13^{10}$ was synthesized by the reaction of $(R, R)$ 1,2-diamino cyclohexane derivative 12 with ethyl chloroformate in the $\mathrm{H}_{2} \mathrm{O}$. followed by lithium aluminum hydride (LAH) reduction in anhydrous THF. The chiral ligand 14 and 15 were prepared through methylation and benzylation as described in Scheme 2. The compound 8 was synthesized by the method with similar yield. ${ }^{11}$

Acknowledgment. This research was supported by the Institute of Clean Technology. Inha University.

\section{References and Notes}

1. (a) Tsuji. I. Tromsition Metals in Organic Sinthesis: Kagaku Dojin: Japan. 1997. (b) Tsuji. J. Palladintm Reagents and Catahsts, Imorations in Organic Swhthesis. John Wiley: 1995: p 290. (c) Trost. B. M.: Van Vranken, D. L.: Bingel, C. J. J. Am Chem Soc 1992. 114,9327 . (d) Trost, B. M.: Bunt. R. C. J. Am. Chem. Soc 1994. 116. 4089. (e) Trost. B. M.: Hachiya. I. J. Am. Chem. Soc 1998. 120.1104 .

2. (a) Togni. A.: Venanzi. L. M. Angew. Chem. Int. Ed Engl 1994. 33. 497. (b) Trost, B. M.: Van Vranken. D. L. Chem. Rer: 1996 96, 395. (c) Ghosh, A. K.; Mathivanan, P.; Cappiello. J. Tettaledron: Aswmetry 1998.9. 1

3. (a) Nishibayashi. Y: Segawa. K.: Takada. H.: Ohe. K.: Uemura. S Chent Commm. 1996. 847. (b) Pretot. R: Pfaltz. A Angew: Chent. Int. Ed. Engl. 1998.37.323.

4. Saito, A.: Monimoto, T.: Achiwa, K. Tetrahedron; Antmetry 1997. 8, 3567

5. Lee. S. G.: Lee, S. H.; Song, C. E.; Chung. B. Y. Tetrahedron: Aswmetry 1999. 10. 1795.

6. Anderson. I. C.: James. D. S.: Mathias. J. P. Tetrahedon: Asnmetry 1998.9.753.

7. Frost. C. G.: Willians. J. M. J. Tetrahtedron Lett. 1993, 34. 2015.

8. Representative procedwe for Pd-catalyzed enamioselective allylic allylation: A mixture of ligand and $\left[\mathrm{PdCl}\left(\eta^{3}-\mathrm{C}_{3} \mathrm{H}_{3}\right)\right]_{2}$ in dry tetrahydrofuran was stirred at room temperature for 30 minl and the resulting solution was treated with a solution of rac-1.3dipheny |-2-propenyl acetate in THF. followed by dimethylmalnonate. BSA. and catalytic amount of KOAc or LiOAc. The misture was stirred at a given temperature, and then the solution was diluted with $\mathrm{CH}_{2} \mathrm{Cl}_{2}$. The organic phase was dried over anhydrous $\mathrm{MgSO}_{4}$. filtered off. and solvent removed under reduced pressure. The crude product was purified by flash columtl chromatography. The conversion was determined by GC analysis and the enantiomeric excess was determined by HPLC analysis (Chiralcel OD-H column: $n$-hexane:2-propanol $=99: 1 ;$ flow rate, $0.5 \mathrm{~mL} \mathrm{~min}$ ).

9. (a) Dawson. G. J: Frost, C. G.: Williams, J. M. J.: Coote. S. J Tetrahedron Lett. 1993. 34. 3149. (b) Kudis. S.: Helmchent. G. Angew: Chent. Int. Ed. Engl 1998.37.3047.

10. Selected data: for NMR (CDCl $3.298 \mathrm{~K}): \delta_{\mathrm{H}}(400 \mathrm{MHz}) 1.25(\mathrm{~m}$. $4 \mathrm{H}) .1 .68(\mathrm{~m}, 4 \mathrm{H}), 2.29(\mathrm{~s}, 6 \mathrm{H}) .2 .66(\mathrm{~m}, 2 \mathrm{H}) .3 .98(\mathrm{dd}, J 2.8 .4 \mathrm{H})$ $6.92-7.2(\mathrm{~m}, 6 \mathrm{H}): \delta(400 \mathrm{MHz}) 22.5,25.9 .27 .3,36.1,54.7 .63 .4$ $124.6,126.3$ and $126.6:[\alpha]_{\mathrm{D}}=-22.98\left(\mathrm{c}=1.0 . \mathrm{CHCl}_{3}\right): \mathbb{R}(\mathrm{KBr})$ 3300.2930 .2790 .1450 .1340 .825 and 690

11. Kiml. Y. K.: Lee. S. T.: Ahn1. K. H J. Org. Chem 2000. 65. 7807 